where many members of staff actively discouraged the term patient in favour of client (1992).

The term client has been used in hospital settings since the 1960s. Its use grew mainly among clinical psychologists and social workers and evolved out of dissatisfaction with the word patient which is thought by some to be loaded with negative aspects such as dependence and powerlessness. The introduction of the term client is thought to break away from these connotations as well as to demedicalise illness. Moreover, increasing commercialisation and medical consumerism in the NHS is encouraging the use of a marketplace vocabulary. However, there are problems and implications associated with the use of the term client beyond semantic and etymological arguments. Its use may cause inappropriate demedicalisation, denial of illness or a detrimental consumerist attitude which could impede treatment and recovery. It may also affect the doctor-patient relationship.

With its undercurrent of passivity, it can also be inappropriate to use the word patient at times, but this problem is not improved by the substitution of patient with client. There are times when the doctor's or nurse's relationship with a patient is one of power and dependency but it is naive to assume that a different name will solve this: the very act of consulting with a health care professional puts a person in a dependent position.

We should be wary about abandoning a term favoured by those to whom it refers. Public opinion may change but for now the 'patient' is alive and well.

\section{References}

MORGAN, H.G. (1992) Suictde prevention - Hazards on the fast lane to community care. British Journal of Psychiatry. 160, 149-153.

SHORE. M.F. (1988) Patient or client? Hospital and Community Psychiatry. 39, 1247.

Sullivan, F. (1992) Patient or consumer? Brtish Journal of General Practice, 358, 213.

Mark W. M. Upton, Registrar in Psychiatry; Harm Boer, Registrar in Psychiatry; and Alastair J. Neale, Registrar in Psychiatry, Wonford House Hospital, Exeter EX2 5AF

\title{
The Mental Illness Specific Grant in Scotland
}

Poor coordination, haphazard implementation

\author{
D.A. Coia, A. McKillop and R.G. McCreadie
}

\begin{abstract}
Our objecttves were to identily and assess the services provided by the Mental IIIness Specific Grant in Scotland and to determine whether they meet government alms for the grant. Scottish Office information proved to be inaccurate on what projects are funded and currently running. Sllppage was common wtth $39 \%$ of projects failing to start in Year 1 and $23 \%$ in Year 2. The grant appears to have funded easy option services, self-help, drop-in, which are less expenstve and only require short-ferm planning. Desplte being oiven priority by the Scottish Omce, housing, supported accommodation and occupation remain unmet needs.
\end{abstract}

The Mental Illness Specific Grant (MISG) was introduced in the National Health Service Com- munity Care Act 1990 to "enable local social services to improve the social care they can provide to people with a mental illness in need of specialist psychiatric care". Access to the grant, according to the guidelines, should be confined to the severely mentally ill, those needing or receiving help from specialist psychiatric services, people with dementia, and those requiring continuing care following brain injury (Scottish Office Circular SW13/1991). The aims of the scheme are to reduce the number of mentally ill people requiring admission to hospital because of lack of resources; to support them living at home; and to enable more people to leave hospital and live with suitable support in the 
community (Scottish Office Circular SW/1990). Projects to be given priority include day activities, day centres, domiciliary services, supported accommodation, respite, crisis services and selfhelp schemes. The grant provides revenue expenditure for new community projects in the field of mental illness and is 'ring fenced'. However, regional authorities must contribute $30 \%$ of the total cost of each project.

Two reports on MISG projects in England (Hogman \& Westall, 1991; 1992) highlighted a number of problems.

(a) Funding. Two of 14 local authorities investigated failed to claim the grant because they were unable to commit the required $30 \%$.

(b) Slippage. Forty-four per cent of projects failed to start on time.

(c) Service. Too little time was allocated for planning, consultation with users and carers and committee approval.

The reports concluded that the introduction of the grant occurred too quickly and was substantially underfunded. These concerns of 'too little, too soon' have been echoed elsewhere (Groves, 1991: Hudson, 1992).

We report a survey of MISG projects in Scotland for grant years 1991/92, and 1992/93. The principal aims of the survey were to review Scottish Office management of the grant; to assess whether the projects fulfilled the stated aims of the grant; and to describe the characteristics of the projects.

\section{The study}

\section{Identification of projects}

The Scottish Office gave us a list of all projects allocated funding in the two grant years. This list (List SO) provided project titles, the amount of grant allocated to each project, and a list of specific grant project co-ordinators within each regional authority. A second list (List RA) was obtained from each regional authority's specific grant co-ordinator for projects in the region. This list provided project titles, addresses, and a contact person for each project.

\section{Procedure}

A psychiatrist who was the project co-ordinator in every Scottish psychiatric hospital was asked to complete a questionnaire about each MISG project in the hospital's catchment area. The projects were identified from List RA. The questionnaire (full details on request) recorded information under the following headings:

(1) project identification and costs

(2) aims
(3) staffing

(4) client volume and characteristics

(5) service type

(6) service function

(7) project evaluation.

Projects were defined as 'started' if they had clients and 'not-started' where there were no clients, even if staff were already employed. The questionnaires were completed during August to October 1992.

\section{Findings}

There was a $100 \%$ response rate from the project co-ordinators which resulted in completed questionnaires for Year $1(1991 / 92)$ on 72 projects, and for Year $2(1992 / 93)$ on 96, of which 66 were continued from Year 1.

\section{Project identification}

We found considerable discrepancy between List SO and List RA. For example, in Year $144 \%$ of projects on List SO were not on List RA and 38\% of projects on List RA were not on List SO. Less than $50 \%$ of projects in three local authority regions on List SO were found on List RA. Two of these three regions had the largest number of projects and populations within Scotland. In only one region were all projects $(n=3)$ on List $S O$ also on List RA. In Year 2 it was impossible to compare List SO with List RA as List SO only provided names of new projects; projects continuing from Year 1 were subsumed under one heading.

\section{Start-up times}

Of the $\mathbf{7 2}$ projects identified and funded in Year $1,28(39 \%)$ had not started by the end of the funding year. Of the 96 projects in Year 2, 22 (23\%) had not started. Of the 66 projects continuing from Year 1, 57 had started by Year 2, but nine still had not. In Year 1 there was considerable variation between regions in the number of projects which had not started; one region, large in population, compared to the rest, had started fewer projects (13 [65\%] v. 15 [29\%] unstarted; $P=0.01$ ). Also in Year 1 , significantly more projects set up by voluntary agencies had started when compared with those set up by social work departments $(28$ [70\%] v. 12 [30\%] started; $P=0.02$ ). By Year 2, however, these differences between regions and between agencies had disappeared.

\section{Match between project and MISG aims}

Aims were stated in $95 \%$ of started projects. These matched the MISG aims (see introduction) in $63 \%$ of started projects. More started than 
Table 1. Service type

\begin{tabular}{|c|c|c|c|c|c|c|c|c|}
\hline \multirow[t]{2}{*}{$\begin{array}{l}\text { Type of } \\
\text { service }\end{array}$} & \multicolumn{2}{|c|}{$\begin{array}{l}\text { Year } 1 \\
\text { Started projects } \\
n=44\end{array}$} & \multicolumn{2}{|c|}{$\begin{array}{l}\text { Not started projects } \\
n=28\end{array}$} & \multicolumn{2}{|c|}{$\begin{array}{l}\text { Year } 2 \\
\text { Started projects } \\
n=74\end{array}$} & \multicolumn{2}{|c|}{$\begin{array}{l}\text { Not started projects } \\
n=22\end{array}$} \\
\hline & $n$ & $\%$ & $n$ & $\%$ & $n$ & $\%$ & $n$ & $\%$ \\
\hline $\begin{array}{l}\text { Community } \\
\text { development }\end{array}$ & 25 & 57 & 18 & 65 & 43 & 58 & 14 & 64 \\
\hline Day centre & 14 & 32 & 10 & 35 & 22 & 30 & 8 & 36 \\
\hline Domicilary & 19 & 43 & 8 & 28 & 28 & 38 & 8 & 36 \\
\hline Drop-in & 20 & 46 & 9 & 32 & 30 & 41 & 8 & 36 \\
\hline Housing & 10 & 22 & 7 & 25 & 17 & 23 & 4 & 18 \\
\hline Residential care & 7 & 15 & 5 & 17 & 13 & 18 & 3 & 14 \\
\hline Resource centre & 20 & 45 & 5 & 17 & 28 & 38 & 4 & 18 \\
\hline Self help & 29 & 66 & 10 & 35 & 42 & 57 & 4 & 18 \\
\hline Other & 15 & 34 & 6 & 21 & 27 & 36 & 5 & 23 \\
\hline More than one & 34 & 78 & 21 & 75 & 58 & 78 & 16 & 73 \\
\hline
\end{tabular}

not-started projects in Year 1 met the aims of the grant (26 [63\%] v. 9 [36\%]; $P=0.05$ ). There was no difference in Year 2.

\section{Characteristics of projects}

Staffing. In Years 1 and 2 two thirds of started projects employed fewer than five staff. Seventynine per cent of all projects employed 'untrained staff, as defined by the project itself, and $44 \%$ of projects employed a mixture of trained and untrained staff. Fifteen and 14 not-started projects in Years 1 and 2 respectively employed at least one member of staff.

Client volume and characteristics. Estimates of the number of clients using the projects were 2,467 in Year 1 and 3,158 in Year 2. These figures exclude seven projects in Year 1 and 15 in Year 2 where numbers were not given. Eighty per cent of projects catered for clients in the age range 16-65 years, $60 \%$ for those over 65 years. Only two projects included patients aged under 16 years. Ninety-five per cent of all projects provided a service to both sexes; one started project was exclusively for women and three started for men.

Two thirds of projects catered for patients with a range of psychiatric diagnoses. A few restricted themselves solely to those suffering from psychosis: $4(9 \%)$ started and $5(18 \%)$ not started in Year $1,6(8 \%)$ started and $3(14 \%)$ not started in Year 2. No other projects were restricted to a single diagnostic group. More projects which had started were for the chronically 111 when compared with those which had not started; this difference was significant in Year 2 (26 [35\%] started v. $1[5 \%]$ not started: $P=0.01$ ). Although $60 \%$ of started projects were aimed at both sufferers and carers, only four started projects were offered solely to carers. Consultation occurred with other organisations including the NHS in over $80 \%$ of all projects.

\section{Type of service}

Most projects provided multiple but limited services as shown in Table 1 . More started projects had self help (Year 1: $P=0.02$; Year 2: $P=0.003$ ), or a resource centre (Year 1: $P=0.03$ ). A drop-in facility was provided by $46 \%$ of started projects in Year 1 and $41 \%$ in Year 2. Provision of day care, housing and residential care was low.

\section{Service functions}

These are defined by the Scottish Office (1992) and the range offered by the projects is shown in Table 2. Most projects again had multiple but limited functions. The four main functions of started projects were social support, advice, advocacy and leisure. Social skills training was offered by $66 \%$ and $62 \%$ of started projects in Years 1 and 2 respectively. Accommodation, support, occupation and employment training were less available. Also identified were two projects that had spent capital.

\section{Evaluation}

Over $90 \%$ of projects stated they were subject to social work evaluation. 'In-built evaluation' occurred in $70 \%$ of projects. Independent evaluations occurred in $43 \%$ and $36 \%$ of started projects in Years 1 and 2 respectively.

Details to assist statistical information are available on request to $\mathrm{Dr}$ Coia.

\section{Comment}

\section{Administration}

Scottish Office listings of projects were inaccurate. Many existing projects were not on the SO 
ORIGINAL PAPERS

Table 2. Service functions

\begin{tabular}{|c|c|c|c|c|c|c|c|c|}
\hline \multirow[t]{2}{*}{ Functions } & \multicolumn{2}{|c|}{$\begin{array}{l}\text { Year } 1 \\
\text { Started projects } \\
n=44\end{array}$} & \multicolumn{2}{|c|}{$\begin{array}{l}\text { Not started projects } \\
n=28\end{array}$} & \multicolumn{2}{|c|}{$\begin{array}{l}\text { Year } 2 \\
\text { Started projects } \\
n=74\end{array}$} & \multicolumn{2}{|c|}{$\begin{array}{l}\text { Not started projects } \\
n=22\end{array}$} \\
\hline & $n$ & $\%$ & $n$ & $\%$ & $n$ & $\%$ & $n$ & $\%$ \\
\hline Social support & 38 & 87 & 23 & 83 & 64 & 86 & 15 & 68 \\
\hline Advice & 36 & 82 & 19 & 68 & 58 & 78 & 18 & 82 \\
\hline $\begin{array}{l}\text { Respite for } \\
\text { carers }\end{array}$ & 17 & 38 & 9 & 32 & 32 & 43 & 10 & 45 \\
\hline $\begin{array}{l}\text { Social skills } \\
\text { training }\end{array}$ & 29 & 66 & 14 & 50 & 46 & 62 & 5 & 23 \\
\hline Leisure & 32 & 73 & 18 & 65 & 49 & 66 & 10 & 45 \\
\hline Advocacy & 34 & 78 & 13 & 54 & 54 & 73 & 15 & 68 \\
\hline Education & 29 & 66 & 15 & 54 & 46 & 62 & 8 & 36 \\
\hline Casework & 20 & 45 & 9 & 32 & 32 & 43 & 6 & 27 \\
\hline $\begin{array}{l}\text { Accommodation } \\
\text { and support }\end{array}$ & 15 & 34 & 9 & 32 & 27 & 36 & 5 & 23 \\
\hline Occupation & 11 & 25 & 8 & 28 & 18 & 24 & 1 & 5 \\
\hline $\begin{array}{l}\text { Employment } \\
\text { training }\end{array}$ & 9 & 20 & 8 & 28 & 21 & 28 & 1 & 5 \\
\hline Treatment & 8 & 18 & 5 & 17 & 15 & 20 & 4 & 18 \\
\hline Other & 6 & 13 & 5 & 17 & 11 & 15 & 4 & 18 \\
\hline More than one & 41 & 94 & 26 & 93 & 70 & 95 & 20 & 91 \\
\hline
\end{tabular}

lists, and conversely some projects on the SO Lists did not exist. Also in Year 2, projects continuing from Year 1 were not individually named. This is in contrast to regional authorities' lists which we found to be accurate and which provided contact data. This discrepancy in information may be due in part to 'slippage'. Local authorities, obliged to spend their first year's money by 1 April 1992, may have found it impossible in the short timescale to set up all their approved projects. Some regions diverted money to other projects which could be established within the timescale. The Scottish Office could not provide us with a list of such projects.

Given current government scrutiny of public spending, surveillance of the Specific Mental Illness Grant seems surprisingly lax. Monitoring in Scotland is carried out by the Social Services Inspectorate (Social Work Services Group, Scottish Office). It has indicated the need to see specific outcomes from the projects (Scottish Office, 1991). However, less than half the projects which had started had independent evaluation. The Scottish Office's own evaluation (1992) is compiled from the original application, and focuses on intentions rather than outcome. The Scottish Office estimated that the projects would provide services for 6,461 people per year. Our estimate of actual usage was very much lower. Money from MISG is specifically for revenue but two projects have used money for capital costs.

\section{Project description}

Our findings that $39 \%$ and $23 \%$ of projects in Years 1 and 2 respectively falled to start is similar to the $44 \%$ average slippage reported in the study of English projects (Hogman \& Westall, 1992). The $39 \%$ of projects failing to start, however, in Year 1 were identified from List RA, which included substitution projects. Therefore the percentage of projects failing to start originally funded from the Scottish Office (List SO) would be much higher. Many not-started projects had employed staff. Difficulty in finding premises contributed to the late start of some projects and seemed to be directly related to social work and health boards being unable to fulfil commitments or promises regarding accommodation. There was considerable variation in regional start-up rates; it is possible, however, that regions with poor start up rates may have had substitute projects which we were unable to identify. Unlike the English survey (Hogman \& Westall, 1992) there was stated consultation in the majority of projects with other organisations, including the health services, but no information on the reality of this.

\section{Government aims}

In line with government aims the majority of projects which had started were aimed at the chronically mentally ill, although few provided for this category exclusively. Also, although 
many projects included carers within their remit few projects were solely for them.

Thirty-seven per cent of started projects in both Years 1 and 2 did not fulfil the aims of the Specific Grant. Was the initial evaluation by the Scottish Office inadequate, did the regions not fully understand the aims, or was it a case of "we must spend the money somehow'? Projects funded by the Grant appeared to address easier areas of service development and function (Tables $1 \& 2$ ). This is in spite of the recommendation that residential, supported accommodation, day care, occupational and employment training be given a high priority (Scottish Office Circular SW 13/1991). It may be that the shortterm nature of the grant, limited funding and short planning cycle precluded such projects.

Details of many projects did, however, indicate to us a number of highly innovative projects, good interagency consultation, considerable enthusiasm and many examples of good practice which must indicate optimism for joint working in the future.

\section{Concluding remarks}

The MISG does not appear to provide a 'needs led' service even though it was intended as such nor does it provide comprehensive help to those severely mentally ill leaving hospital. Provision of housing, supported accommodation, occupational and employment training, despite being a clearly identified need, remains unmet in some areas and may in the future be achieved more successfully if better co-ordination is achieved between the specific grant and bridging finance. There appears to be a lack of centralised planning, and inaccurate central information, despite the availability of accurate regional data.

\section{Acknowledgements}

The study was carried out under the auspices of the Rehabilitation Group, Scottish Division, Royal College of Psychiatrists. We would like to thank the Scottish Office, the Specific Grant Co-ordinators and the following Hospital Coordinators: Dr N. Ali, Dr R. Athawes, Dr D. Ball, Dr J. Bouch, Dr T.V.K. Chandrasekhar, Dr I. Clark, Dr F. Corrigan, Dr G. Crocket, Dr P. Dick, Dr A. Drayson, Dr J. Flowerdew, Dr S. Gilfillan. Dr D.D. Hendry, Dr D. Jones, Dr A. Lodge, Dr D. McNab, Dr I. Pullen, Dr T. White, Dr A Yellowlees. Dr J.M. Atkinson made constructive comments on an earlier draft of this paper.

\section{References}

Groves, T. (1991) The Mental Illness Grant: too little, too soon. British Medical Journal. 302, 1416.

Hogman. G. \& Westall. J. (1991) Mental Mlness Specific Grant: the early days. Kingston. Surrey: National Schizophrenia Fellowship.

- (1992) Window Dressing. Research Findings on the Care Programme Approach and The Mental Illness Specific Grant. Kingston. Surrey: National Schizophrenia Fellowship.

HUDSON. B. (1992) Misguided money. Health Services Journal, July, 26-27.

THE SCOTTSH OfFice (1991) Community Care in Scotland: monitoring and evaluating community care. Edinburgh

- (1992) Scottish Office Evaluation. Community Care in Scotland: Spectfic Grant for Mental Illness 1991-92. Applications and Approvals. Edinburgh.

*D. A. Coia, Consultant Psychiatrtst; A. McKillop. GP Trainee, Florence Street Day Hospital, 26 Florence Street, Glasgow G5 OYX; and R. G. McCreadie, Director of Clinical Research, Crichton Royal Hospital, Dumfries DG1 4TG

*Correspondence 